\title{
A Precise Guidance for Fair Local Communities' Development Investments Allocation, Case Study: Damietta Governorate, Egypt
}

\author{
Asmaa Abdel Aty Mohamed Ibrahim \\ Architecture Department, Faculty of Engineering, \\ Cairo University, 23 El Etihad Square, street 106, Maadi, Cairo, Egypt \\ asmaaabaty2@gmail.com, asmaaabaty@gmail.com
}

\begin{abstract}
Integrated statistical-theoretical based approaches in decision support promise to support effective investment decision making. From this view, this paper proposes an innovative methodology to digitally indicate the true developmental level of villages (the smallest Egyptian local units), which would accordingly provide a precise guidance for fair investments' allocation according to their needs' priorities. This would be achieved through testing 158 variables; taking Farscour district in Damietta Governorate in Egypt as a case study. Accordingly, this paper comes out with a statistical methodology that enables decision makers' map out the most deteriorated local communities and to set up investment priorities.
\end{abstract}

Keywords: Socio-cultural Aspects; Urbanization; Local Communities' Needs; Development Challenges; Investment Priorities

eISSN 2398-4295 @ 2018. The Authors. Published for AMER ABRA cE-Bs by e-International Publishing House, Ltd., UK. This is an open-access article under the CC BY-NC-ND license (http://creativecommons.org/licenses/by$n c-n d / 4.0 /$ ). Peer-review under responsibility of AMER (Association of Malaysian Environment-Behaviour Researchers), ABRA (Association of Behavioural Researchers on Asians) and $c E-B s$ (Centre for EnvironmentBehaviour Studies), Faculty of Architecture, Planning \& Surveying, Universiti Teknologi MARA, Malaysia.

DOI: http://dx.doi.org/10.21834/ajbes.v3i9.55 


\subsection{Introduction}

Decision-making is a very complex activity because of the interdependencies which exist between reasoning and making decisions (Johnson-Laird and Shafir, 1993).

\subsection{Overview on Decision Theories}

When the feasible set of alternatives of a decision consists of a finite number of elements that are explicitly known in the beginning of the solution process, we have an important class of problems called multi criteria evaluation problems. When the number of alternatives of a decision is uncountable infinite, the alternatives are not specified directly, but are defined in terms of decision variables as is usually done in single optimization problems like' linear programming. This type of problem is called a continuous decision problem in which the alternatives are only implicitly known. It is referred to as a multi criteria design problem. Here is a listing of many decision techniques found in the literature; Multi criteria evaluation methods, the outranking approach (Software Electra) by Roy (B. Roy, 1981) and Roy and Vincke (B. Roy and P. Vincke, 1981), other methods developed by some French-Belgian school researchers are: Oreste by Roubens (M. Roubens, 1982) and Pastijn and Leysen ( $H$. Pastijn and J. Leysen, 1989). Others by Newman J.W., 1971), Steuer R. and Choo E.U., 1983; Wierzbicki A., 1980; Zadeh L.A., 1965; Zimmermann H.J., 1991; Zionts S. and Wallenius J., 1976.

\subsection{Proposal and Classification of Variables Used in the Statistical Analysis}

The variables used in this research were proposed and filtered according to the data available in the Central Agency for Public Mobilization and Statistics (CAPMAS) to 158 variables. These were classified into urban, economic, and social (demographic, educational, health care, cultural, and social services) variables and are shown in table (2). They were collected for the 22 villages and the two cities in Farscour district due to the continuous change in the administrative borders between cities and villages and would thus be all included within the coming statistical analyses.

\subsection{Defining Steps for the Proposed Decision Making Process}

Since all the above listed variables, which all contribute in defining the developmental level of any planning unit and in defining their requirements were so many and confusing, the statistical analysis was the best method selected to reach the most precise results using the SPSS (Statistical Package for Social Sciences) program by the factor analysis (the principal component method). It is one of the methods that are used for the exploration and the detection of patterning of variables with a view to the discovery of the new concepts, together with confirmatory uses for the testing of hypothesis about the structuring of variables in terms of the expected number of significant factors and factor scores. It classifies all the tested variables into components, each having a percentage for representing the strength of its 
correlated variables in affecting the results, called the total variance explained which validates the test when it is above $30 \%$. The component loadings on the other hand is an absolute number describing the strength of each variable inside these components and is considered effective when its absolute values is 0.5 or above. (Nie et al, 1975). Finally, the factor scores represent the strength of each of the case studies tested in this analysis (with numbers relative to each other). Four main analyses were undertaken according to the following steps.

The following points explain these tests and their results briefly as all the resulting tables cannot be shown in the paper. The author has thus highlighted the main results as follows, with indication of all the factor scores in Table 1 and an example of the component matrix results in Table 2:

Table 1: Results for the factor scores of the different statistical steps carried out

\begin{tabular}{lllll}
\hline Planning Units' Names & Factor scores & Factor scores & Factor scores & Factor scores \\
& Step 1 & Step 2 & Step 3 & Step 4 \\
\hline Farscour city & 4.09 & 4.19 & & \\
Al Roda city & 1.75 & 1.62 & & \\
Sherbas & 0.49 & 0.41 & 3.00 & 3.07 \\
Al Rahmna & 0.17 & 0.08 & 1.41 & 1.32 \\
Abo Greida & -0.50 & -0.45 & -0.85 & -0.73 \\
El Azazma & -0.62 & -0.56 & -1.09 & -1.05 \\
El Obeidia & -0.33 & -0.33 & -0.36 & -0.39 \\
El Tarha & -0.56 & -0.54 & -0.84 & -0.84 \\
El Barashia & -0.38 & -0.36 & -0.32 & -0.29 \\
El Ghwabein & -0.28 & -0.27 & -0.04 & 0.01 \\
Awlad Khalaf & -0.35 & -0.36 & -0.34 & -0.25 \\
El Ghoneimia & 0.02 & 0.00 & 0.89 & 0.91 \\
El Dhara & -0.32 & -0.31 & -0.33 & -0.34 \\
El Salemia & -0.61 & -0.57 & -1.26 & -1.24 \\
El Nagareen & -0.44 & -0.43 & -0.72 & -0.72 \\
Kafr El Arab & 0.00 & -0.05 & 1.02 & 0.84 \\
Kafr El Shenawy & -0.50 & 0.47 & -0.77 & 0.89 \\
El Nasria & 0.17 & 0.16 & 1.35 & 1.48 \\
Karam wa Razook & -0.21 & -0.17 & -0.17 & -0.17 \\
El Arbein & -0.40 & -0.38 & -0.52 & -0.55 \\
El Hawarni & -0.24 & 0.26 & 0.09 & 0.06 \\
Meit El Shoyokh & -0.45 & 0.45 & -0.47 & $-0.44-$ \\
El Atwi & 0.27 & -0.27 & 0.13 & 0.10 \\
Hagaga & -0.22 & -0.26 & 0.18 & 0.10 \\
\hline & & & &
\end{tabular}

- In the first test, all the variables for the 22 villages and the two cities were tested. The first component has shown that the total variance explained reached $50 \%$ and this is a relatively high score. The factor scores revealed that the highest scores were occupied by the cities followed by sherbas, whereas the less developed villages is clearly the one with the lowest factor score, which is El Azazma. From the component matrix, the highest component loadings were for the social variables (educational services) followed by the economic and demographic variables, as shown in table (2).

- In the second test, another run was performed after excluding all the weak variables whose component loadings were less than 0.5 to ensure the accuracy of these results. 
The variables entered were 90 variables. The results have yielded the same findings explained in the first test.

- In the third test, all the variables were tested but without the two cities, to ensure that their data do not affect the rest of the results. The total variance explained here was $30.45 \%$, and the highest factor score was for sherbas and the lowest one was for El Azazma. From the component matrix, the highest component loadings were for the social variables (educational services) followed by the economic and demographic variables.

- In the fourth test, only strong variables including 61 variables, whose component loadings were more than 0.5 , were tested to ensure the accuracy of these results. The results have yielded the same findings explained in the third test.

Table 2: Resulting component matrix from the first test

\begin{tabular}{|c|c|c|c|c|c|}
\hline & $\begin{array}{l}\text { Urban } \\
\text { variables }\end{array}$ & & Social variables & & Economic variables \\
\hline \multirow[t]{2}{*}{0.450} & $\begin{array}{l}\text { Length of } \\
\text { paved road }\end{array}$ & & $\begin{array}{l}\text { Social } \\
\text { (Demographic } \\
\text { variables) }\end{array}$ & 0.596 & $\begin{array}{l}\text { Number of commercial } \\
\text { buildings }\end{array}$ \\
\hline & \multirow{12}{*}{$\begin{array}{l}\text { Length of } \\
\text { smoothed } \\
\text { road } \\
\text { Length of } \\
\text { unsmoothed } \\
\text { road }\end{array}$} & 0.968 & $\begin{array}{l}\text { Number of } \\
\text { population } 1986\end{array}$ & 0.911 & $\begin{array}{l}\text { Number of industrial } \\
\text { buildings(factories/wor } \\
\text { kshops) }\end{array}$ \\
\hline \multirow[t]{11}{*}{0.713} & & 0.944 & $\begin{array}{l}\text { Number of } \\
\text { population } 1996\end{array}$ & -0.076 & $\begin{array}{l}\text { Value of exported } \\
\text { products }\end{array}$ \\
\hline & & -0.338 & Annual Growth rate & -0.092 & $\begin{array}{l}\text { Value of local } \\
\text { products }\end{array}$ \\
\hline & & -0.163 & $\begin{array}{l}\text { Percentage from } \\
\text { district population }\end{array}$ & 0.229 & Local income \\
\hline & & -0.265 & Average family size & 0.179 & $\begin{array}{l}\text { Number of touristic } \\
\text { rooms }\end{array}$ \\
\hline & & 0.774 & $\begin{array}{l}\text { Number of families } \\
1996\end{array}$ & 0.271 & $\begin{array}{l}\text { Number of touristic } \\
\text { beds }\end{array}$ \\
\hline & & 0.944 & $\begin{array}{l}\text { Number of } \\
\text { population } 2002 \\
\text { Number of }\end{array}$ & 0.876 & $\begin{array}{l}\text { Number of annual } \\
\text { touristic visitors } \\
\text { Number of owners- }\end{array}$ \\
\hline & & 0.944 & $\begin{array}{l}\text { population } 2007 \\
\text { Estimated Number }\end{array}$ & 0.005 & $\begin{array}{l}\text { females } \\
\text { Number of owners- }\end{array}$ \\
\hline & & 0.944 & of population 2012 & 0.072 & males \\
\hline & & 0.944 & $\begin{array}{l}\text { Estimated Number } \\
\text { of population } 2017\end{array}$ & 0.576 & $\begin{array}{l}\text { Number of owners- } \\
\text { males and females }\end{array}$ \\
\hline & & 0.944 & $\begin{array}{l}\text { Estimated Number } \\
\text { of population } 2022\end{array}$ & -0.075 & $\begin{array}{l}\text { Cultivated land area- } \\
\text { (feddan-thousands) }\end{array}$ \\
\hline & & & $\begin{array}{l}\text { Social (Educational } \\
\text { services) }\end{array}$ & 0.138 & $\begin{array}{l}\text { Cultivated land area- } \\
\text { kirates }\end{array}$ \\
\hline
\end{tabular}




\begin{tabular}{|c|c|c|c|}
\hline 501 & $\begin{array}{l}\text { Number of primary } \\
\text { schools } \\
\text { Number of Islamic } \\
\text { Azhari primary } \\
\text { schools }\end{array}$ & -0.033 & $\begin{array}{l}\text { Cultivated land area- } \\
\text { sahm } \\
\text { Crop composition } \\
\text { (cultivated area- } \\
\text { feddans) }\end{array}$ \\
\hline 791 & $\begin{array}{l}\text { Total number of } \\
\text { primary schools }\end{array}$ & 0.086 & $\begin{array}{l}\text { Crop composition } \\
\text { (cultivated area- } \\
\text { kirates) }\end{array}$ \\
\hline 699 & $\begin{array}{l}\text { Number of } \\
\text { preparatory schools }\end{array}$ & -0.050 & $\begin{array}{l}\text { Crop composition } \\
\text { (cultivated area-sahm) }\end{array}$ \\
\hline 825 & $\begin{array}{l}\text { Number of Islamic } \\
\text { Azhari preparatory } \\
\text { schools }\end{array}$ & 0.576 & hicken \\
\hline 835 & $\begin{array}{l}\text { Total number of } \\
\text { preparatory schools } \\
\text { Number of }\end{array}$ & -0.075 & $\begin{array}{l}\text { Number of eggs from } \\
\text { chicken labs } \\
\text { Number of produced }\end{array}$ \\
\hline 746 & & 0.138 & \\
\hline 325 & $\begin{array}{l}\text { r of Islamic } \\
\text { secondary }\end{array}$ & -0.033 & loney cells \\
\hline 882 & $\begin{array}{l}\text { umber of } \\
\text { ary schools }\end{array}$ & 0.171 & $\begin{array}{l}\text { Number of livestock- } \\
\text { milk }\end{array}$ \\
\hline 33 & $\begin{array}{l}\text { Number of } \\
\text { technical secondary } \\
\text { school }\end{array}$ & .08 & $\begin{array}{l}\text { lumber of livestock- } \\
\text { leat- female }\end{array}$ \\
\hline & $\begin{array}{l}\text { Number of classes } \\
\text { (primary- } \\
\text { preparatory- }\end{array}$ & & $\begin{array}{l}\text { umber of livestock- } \\
\text { eat- male }\end{array}$ \\
\hline 0.986 & & .050 & \\
\hline 988 & of high & .430 & $\begin{array}{l}\text { er of } \\
\text { eat }\end{array}$ \\
\hline 979 & $s$ & -0.109 & $\begin{array}{l}\text { Coffee production- } \\
\text { tons }\end{array}$ \\
\hline 0 & $\begin{array}{l}\text { Number of female } \\
\text { teachers (primary- } \\
\text { preparatory- } \\
\text { secondary) }\end{array}$ & 0.60 & $\begin{array}{l}\text { ricity } \\
\text { year) }\end{array}$ \\
\hline 21 & $\begin{array}{l}\text { Number of male } \\
\text { teachers (primary- } \\
\text { preparatory- } \\
\text { secondary) }\end{array}$ & 0.589 & $\begin{array}{l}\text { Number of commercial } \\
\text { members in electric } \\
\text { network }\end{array}$ \\
\hline & umber of & 0.2 & $\begin{array}{l}r \text { of connected } \\
\text { in electric }\end{array}$ \\
\hline
\end{tabular}


Number of male students in first

0.911 primary

Number of female

students in first

0.912 primary

Total number of students in first

0.913 primary

Total number of male students in all

0.992 stages

Total number of female students in

0.990 all stages

Number of enrolled students (primarypreparatory-

0.992 secondary) Number of enrolled

0.992 students

Number of

0.965

illiterates

Number of literacy

-0.060 target groups

Number of enrolled in literacy classes -

-0.025 females

Number of enrolled in literacy classes -

0.146 males

Number of pass in literacy classes -

0.078 females

Number of fail in literacy classes -

males

Number of un-

-0.059 enrolled in literacy network

Residential electricity

consumption(Kw/year)

Industrial electricity

0.980

consumption(Kw/year)

Number of residential members connected

0.565 to sewage system Number of industrial members connected

0.817 to sewage system Number of houses connected to sewage

0.512 pipes

Total number of houses connected to sewage pipes or systems Average water

0.971 consumption

Number of families connected to water

0.973 network

Number of residential units connected to water network

Number of members

in water network

Number of residents connected to

0.535 telephone network

Number of nonresidents connected to

0.713 telephone network Number of residents connected to communication

0.935 network Number of non0.813 residents connected to 


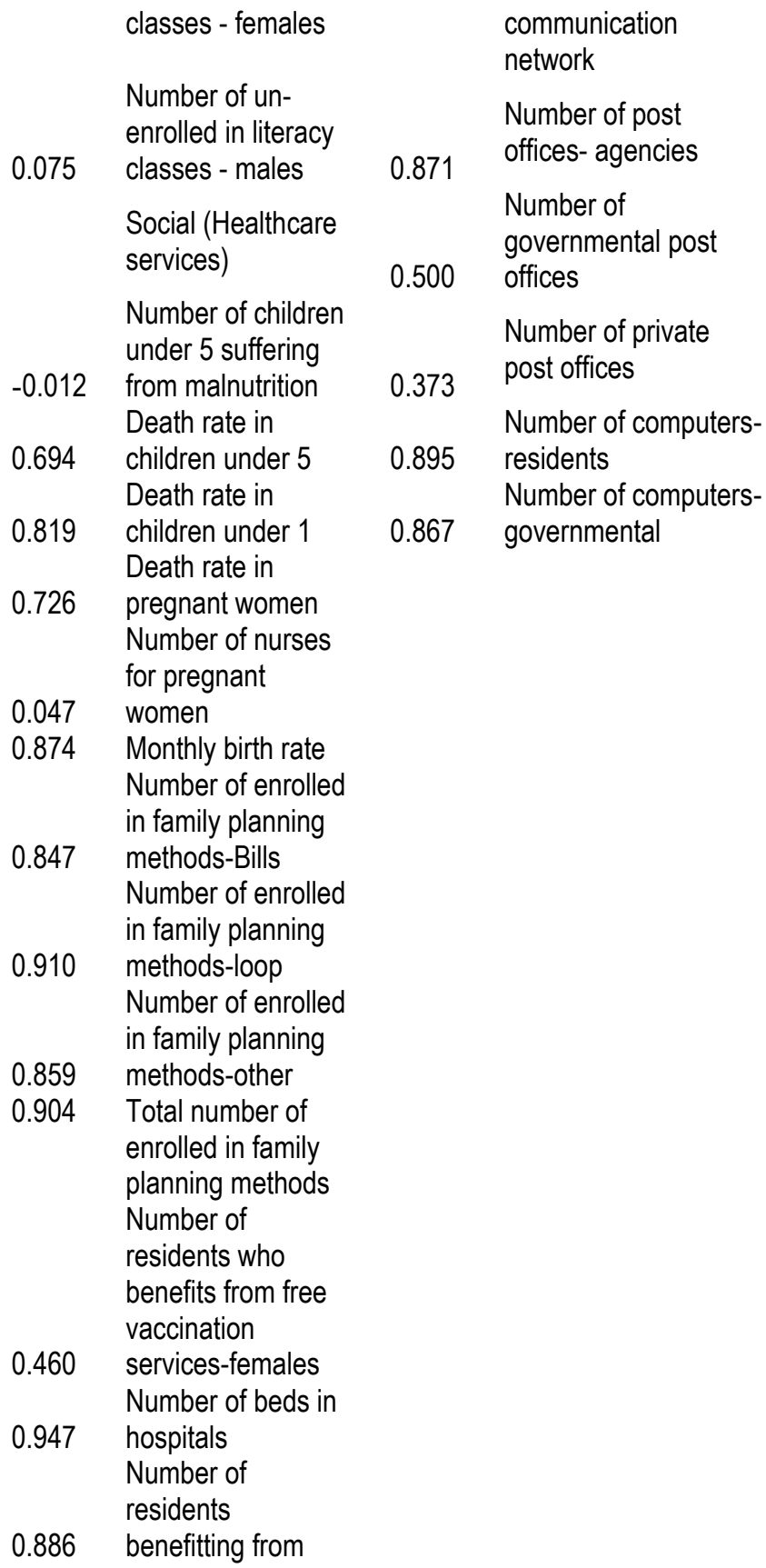

Number of unenrolled in literacy

Number of children under 5 suffering

0.886 benefitting from 
maternity and childhood services

Number of mothers

0.867 taking vaccinations

Number of

residents going to

0.021 clinics

Number of

residents

benefitting from

0.708 pregnancy services

Number of

pregnant women

suffering from

0.885 Anaemia

0.029 Number of doctors

Number of

0.137 nurseries

0.938 Number of nurses

Number of medical

0.871 helpers

Number of

0.332 permanent workers

0.941 No, of labs' workers

Number of

employees in

medical

0.886 administrations

Number of

0.269 socialists

Number of

technicians in

0.793 hospitals

Number of

-0.068 temporary workers

Total number of

workers and

0.863 helpers in hospitals

Number of health

0.882 units

Social

(Entertainment

services) 


\begin{tabular}{|c|c|}
\hline 0.871 & Number of clubs \\
\hline & Number of youth \\
\hline 0.092 & centres \\
\hline & Number of playing \\
\hline 0.387 & courts \\
\hline & Number of sports' \\
\hline 0.31 & centres \\
\hline . & $\begin{array}{l}\text { Number of local } \\
\text { gathering nodes }\end{array}$ \\
\hline & $\begin{array}{l}\text { Social (cultural } \\
\text { services) }\end{array}$ \\
\hline & Number of public \\
\hline & $\begin{array}{l}\text { libraries } \\
\text { Number of cultural }\end{array}$ \\
\hline 0.89 & centres \\
\hline
\end{tabular}

0.104 libraries

0.961 Number of theatres

0.886 Number of cinemas

Number of distributed daily

-0.022 journals Social (social services) Number of civil societies'

0.397 organizations

Number of members in these-

0.694 female Number of members in these-

0.899 male Number of members in these-

0.863 kids female Number of members in these-

0.911 kids male Number of families benefiting from their

0.353 services

0.408 Number of citizens 
benefiting from their

services

Number of families

benefiting from

productive family

-0.159 project

Number of

governmental

0.632 social units

Number benefiting

from exceptional

-0.176 pensions

Number benefiting

from permanent

0.930 pensions

Daily consumed

0.963 flour(tons)

Daily consumed

0.943 gas

Number of commercial

0.574 markets

Number of basic

0.971 food supply cards

Number of partial

financed food

0.724 supply cards

0.723 Number of totally

financed food

supply cards

It is clear from the previous statistical analyses that the two main cities in Farscour district are dominant and represent a separate developmental entity isolated from the rest of the villages existing within its administrative border, and which are much deteriorated. This represents a clear proof for the extreme centralization that Farscour and Al Rowda cities have full control of. This was obviously clear from the results of the four tests which yielded the same findings with or without the cities, as most of the factor scores of the villages were negative, and have slightly increased after excluding the cities and the weak variables. 


\subsection{Conclusion}

Multi-sectorial systems, such as cities and local communities' entities (villages), face strategic challenges of optimal development due to the complexity of interacting perspectives, and preferences of decision-makers and stakeholders. From this view, this paper has presented an integrated statistical-theoretical based approach in decision support to generate effective results and to guarantee fair investment allocation plans. This has been achieved through testing 158 variables classified into urban, social and economic variables by the factor analysis (principal component) using the SPSS program on the local units and cities comprising Farscour district in Damietta Governorate to end up with a precise numerical value for each planning unit describing its developmental level as compared to each other.

\section{Acknowledgement}

I would like to thank Dr. Tarek Abdel Latif Aboul Atta, for giving be the opportunity to work in this research as part of a project undergone by his Planning Consultancy Office, and for his supervision and valuable comments throughout all the procedures of this work. The research was fully funded by the author.

\section{References}

Johnson-Laird, P.N., Shafir, E. (1993). The interaction between reasoning and decisionmaking: An introduction. International Journal of Cognitive Science 49 (1/2).

Newman J.W. (1971). Management Applications of Decision Theory, Harper \& Row.

Nie N. et al (1975), "SPSS: Statistical package for the social sciences", USA: Mc Graw-Hill, 276-470.

Pastijn H. and Leysen J. (1989). Constructing an outranking relation with ORESTE, Mathl. Compute. Modelling 12 (IO/II), 1255-1268.

Roubens M. (1982). Preference relations on actions and criteria in multi criteria decision making, European Journal of Operational Research, 10, 51-55.

Roy B. and Vincke P. (1981). Multi criteria analysis: Survey and new directions, European Journal of Operational Research 8, 207-218

Roy B., (1981). How outranking relation helps multiple criteria decision making, Topics in Multiple Criteria Decision Making (ed. by J. Cochrane and M. Zeleny). University of South Carolina Press, 179-201. 
Steuer R. and Choo E.U. (1983). An interactive weighted Tchebycheff procedure for multiple objective programming, Mathematical Programming, 26, 326-344.

Wierzbicki A. (1980). The use of reference objectives in multi objective optimization, Topics in Multiple Objective Decision Making: Theory and Application (ed. by G. Fandel and T. Gal), Springer-Verlag.

Zadeh L.A., (1965). Fuzzy sets, Information and Control 8 (3), 338-353.

Zimmermann H.J. (1991). Fuzzy Set Theory and Its Applications. (2nd ed.), Kluwer, Boston, MA.

Zionts S. and Wallenius J. (1976). An interactive programming method for solving the multiple criteria problem, Management Science, 22, 652-663. 